Article

\title{
A Conceptual Framework for Heuristic Progress in Exploring Management Regime Shifts in Biodiversity Conservation and Climate Change Adaptation of Coastal Areas
}

\author{
Raphaël Mathevet ${ }^{1,2, *}$, Aurélien Allouche ${ }^{3,4}$, Laurence Nicolas $^{3}$, Veronica Mitroi ${ }^{5}$, \\ Christo Fabricius ${ }^{6,7}$, Chloé Guerbois ${ }^{6}$ and John M. Anderies ${ }^{8}$ \\ 1 Centre d'Ecologie Fonctionnelle et Evolutive, UMR 5175, CNRS-Université de Montpellier-Université \\ Paul-Valéry Montpellier-EPHE, 1919 route de Mende, 34293 Montpellier CEDEX 5, France \\ 2 Institut Français de Pondichéry, UMIFRE 21 CNRS/MAEE, 11 Saint Louis Street, Puducherry 605001, India \\ 3 RESSOURCE, 3095 route de Boulbon, 13570 Barbentane, France; aurelien.allouche@laposte.net (A.A.); \\ laurence.b.nicolas@wanadoo.fr (L.N.) \\ 4 Laboratoire Méditerranéen de Sociologie, CNRS-Université Aix-Marseille, UMR 7305, France \\ 5 Institut d'Ecologie et Sciences de l'Environnement de Paris-iEES Paris, Université Pierre et Marie Curie, \\ 4 Place Jussieu, 75005 Paris, France; veronica.mitroi@leesu.enpc.fr \\ 6 Sustainability Research Unit, Nelson Mandela University, P.O.Box 6531, George 6530, South Africa; \\ christo.Fabricius@wwf.org (C.F.); Chloe.Guerbois@mandela.ac.za (C.G.) \\ 7 World Wildlife Fund (WWF), c/o Nelson Mandela University, George 6530, South Africa \\ 8 School of sustainability, Arizona State University, P.O. Box 875502, Tempe, AZ 85287-5502, USA; \\ m.anderies@asu.edu \\ * Correspondence: raphael.mathevet@cefe.cnrs.fr
}

Received: 28 August 2018; Accepted: 30 October 2018; Published: 13 November 2018

\begin{abstract}
Social conflicts related to biodiversity conservation and adaptation policy to climate change in coastal areas illustrate the need to reinforce understanding of the "matters of concern" as well as the "matters of fact". In this paper, we argue that we must rethink adaptation from a new perspective, considering that humans together function as both ecological actors and social actors. Using international examples from the UNESCO world biosphere reserve network, we show that an ontological perspective may provide a simple and compact way to think about coupled infrastructure systems and systematic formalism, allowing for understanding of the relational matrix between actors, institutions and ecosystems. We contend that our formalism responds to three challenges. First, it encompasses the different regional contexts and policies that rely on the same ontology. Second, it provides a method to relate any local adaptation plan to the conservation paradigms that originate from the ecological modernization of policies. Third, it facilitates the discovery of drivers and processes involved in adaptation and management regime shifts by highlighting the way contextual factors configure, determine the structure of the action situation of the Institutional Analysis and Development framework (IAD) (Ostrom 2005), and how it operates.
\end{abstract}

Keywords: ontology; IAD framework; adaptation; management regime; social-ecological system; biosphere reserves; Camargue; Danube; Garden Route

\section{Introduction}

A range of policies addressing global change adaptation exists, depending on the geographical context and local historical features of coastal areas [1]. A growing number of studies indicate the complementarity but also the competing interests existing between two paradigms of adaptation, 
namely, adaptation based-on hard infrastructures (e.g., seawalls and breakwater construction for shoreline protection, [2]) and adaptation with ecological engineering or ecosystem-based adaptation (e.g., realignment of human activities, ecosystem conservation or restoration, [3]). This context gives rise to not only a technological and financial issue but also a social, normative and political challenge in reconciling the goals of climate change adaptation with those of ecosystem conservation [4-6].

In the Anthropocene, human beings have demonstrated their capacity to alter the climate, land cover and biodiversity at various spatial and temporal scales [7]. Therefore, addressing climate change adaptation, natural resource management and biodiversity conservation requires a re-examination of the dynamics of and interactions between political, social and ecological processes involved in decision-making [8-11]. While social-ecological or coupled natural-human systems dynamics have been extensively explored [12,13], few authors have tried to decode the rules, norms, or strategies observed in action arenas [14] or to compare and study dissimilarities and connections in how various human-environment approaches frame the analysis of their object of study [15].

In this paper, we propose to rethink stakeholders' management of and adaptation to global change by using a social-ecological ontology describing the relationships among natural and man-made objects and/or humans, and integrating the social and natural interdependence influencing decision making. This conceptual perspective is rooted in sustainability sciences, ecology, sociology and environmental philosophy. It highlights the way contextual factors shape the organization of the Action Situation of the Institutional Analysis and Development framework of Ostrom [16].

The objectives of this paper are thus to explore the bi-directional influences between different ontologies and management regimes, and to identify how social-ecological processes emerge as an outcome of management design and implementation. To address these objectives, we first define the notion of social-ecological ontology and how it translates into multiple management regimes. Secondly, we apply this ontological approach to the study of management regime shifts and re-combinations in three coastal case studies: the Camargue Biosphere Reserve in southern France, the Danube Biosphere Reserve in Romania and the Garden Route Biosphere Reserve in South Africa. In the last section, we discuss the applicability and value of the proposed ontology and suggest future directions for both research and policy.

\section{A Social-Ecological Ontology to Question Matters of Concern}

Ontology relates to understanding knowledge and process of knowledge construction in relationship to the nature of existence $[17,18]$. Creating ontologies is a first step in science [18] especially in the study of complex systems. Ontologies can be considered as framings or models for understanding reality aiming to describe the relationship between human beings and their environment. An ontology provides a common grammar. Among the rare authors that have developed an ontology to decode rules or to compare framings, Ostrom and her collaborators have developed the IAD framework to link theory and practice, analysis and policy $[14,16]$. This framework aims to cope with the complexity of any policy analysis and one key component of the IAD framework is the "action situation" which is shaped by contextual factors such as biophysical conditions (i.e., biophysical dimensions but also type of goods), attributes of the community (i.e., trust level, shared norms) and rule-in-use (i.e., formal and informal rules). Thus, the IAD framework is useful for highlighting how the biophysical, social-cultural and institutional context shapes decisions made by different individuals who interact in the Action Situation; aggregated decisions form, with other exogenous factors, the observable outcomes that will feed back into the components of the described system (Figure 1). However, Ostrom [16,19] and later works [20,21] were never explicit about the way to organize our thinking around the key arrow that links the contextual factors to Action Situation. 


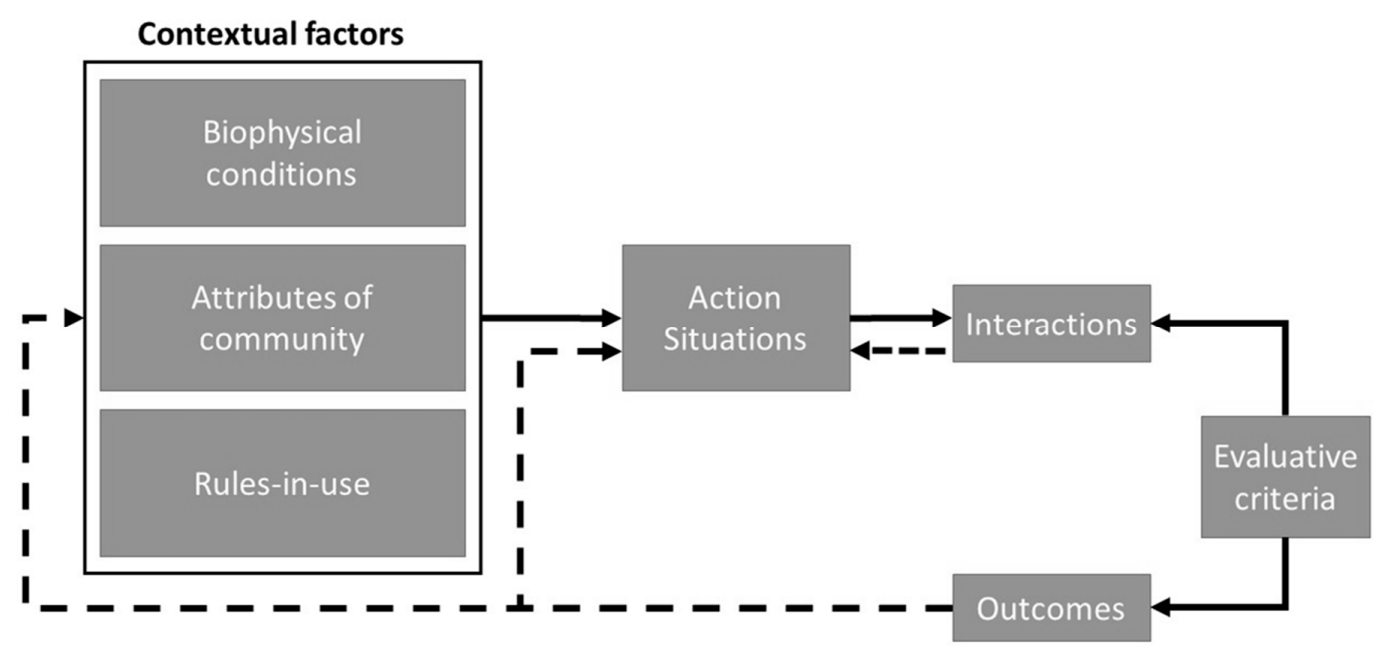

Figure 1. Institutional Analysis and Development framework [17].

Management interventions are framed by ontological assumptions that in turn guide the choices of actions, rules and techniques used, and the way results are interpreted and publicized. As the relevance of the explanatory elements' frames management interventions and their potential success, the use of an ontology can improve the capacity of management agencies to explicitly consider these explanatory elements. The ontological perspective is particularly helpful in reducing ambiguity when researchers and practitioners from multiple disciplines and sectors collaborate, as is often the case in global change adaptation $[9,15,18]$. Hence the importance of a simple and systematic formalism that allows for understanding of the relational matrix between actors (resource use), institutions (resource management) and ecosystems (nature). This formalism should address three needs. First, because land use and climate change adaptations are essentially a global challenge, there is a crucial need for simple, generalizable formalisms that encompass the different regional contexts and adaptive policies that rely on the same agency. Second, an ontological formalization of social-ecological agencies allows us to relate any local adaptation plan to the conservation paradigms that originate from the ecological modernization of policies [22]. Third, such grammar can unravel resilience factors, as well as nurture the discussion around the adaptive processes of management regimes (i.e., the implicit or explicit principles, norms, rules, and decision-making processes around which actors expectations in land and natural resource management converge, adapted from [23]), by highlighting the way contextual factors determine the structure of the Action Situation of the IAD framework, and how it operates.

There are numerous ways of categorizing an object other than being merely natural or merely social. Indeed, a dialectical view of people and nature is a human construct that might lead to analytical and conceptual flaws. As Bruno Latour [24,25] has emphasized, there are multiple realities which can only be understood by focusing on "matters of concern" instead of simple "matters of fact", especially when several actors interact within the same natural system. Many social conflicts that involve adaptation and regional planning occur because we use the conditions of the truth in one domain (e.g., ecology) to review the reliability of another domain (e.g., sociology). Objects (i.e., living things and physical things) have different modes of existence, and our misunderstanding often comes from categorization failures [26-28]. We should characterize the diversity of reality, not to understand things themselves but rather to understand their ways of being or modes of existence; in other words, their social-ecological ontology.

We propose to characterize specific social-ecological ontology in a management regime with three building blocks signified by "M.A.N." (Figure 2). "M" refers to resource Management, which (similar to institutions in common property theory [29]) is defined as a set of principles, norms, rules and decision-making procedures for the (non)use of a plot of land, an estate, an ecosystem or a species (e.g., grazing pressure, water management, etc.). Management also encompasses the technical tools and practices to manipulate or transform natural resources. This includes monitoring and sanctioning 
tools. "A" refers to human Activities, their finalities and land use (e.g., conservation, hunting, farming), but also nature appropriation; and (iii) " $\mathrm{N}$ " refers to Nature, in the sense of biodiversity and ecological functions resulting from a spontaneous nature or from a human-made nature.
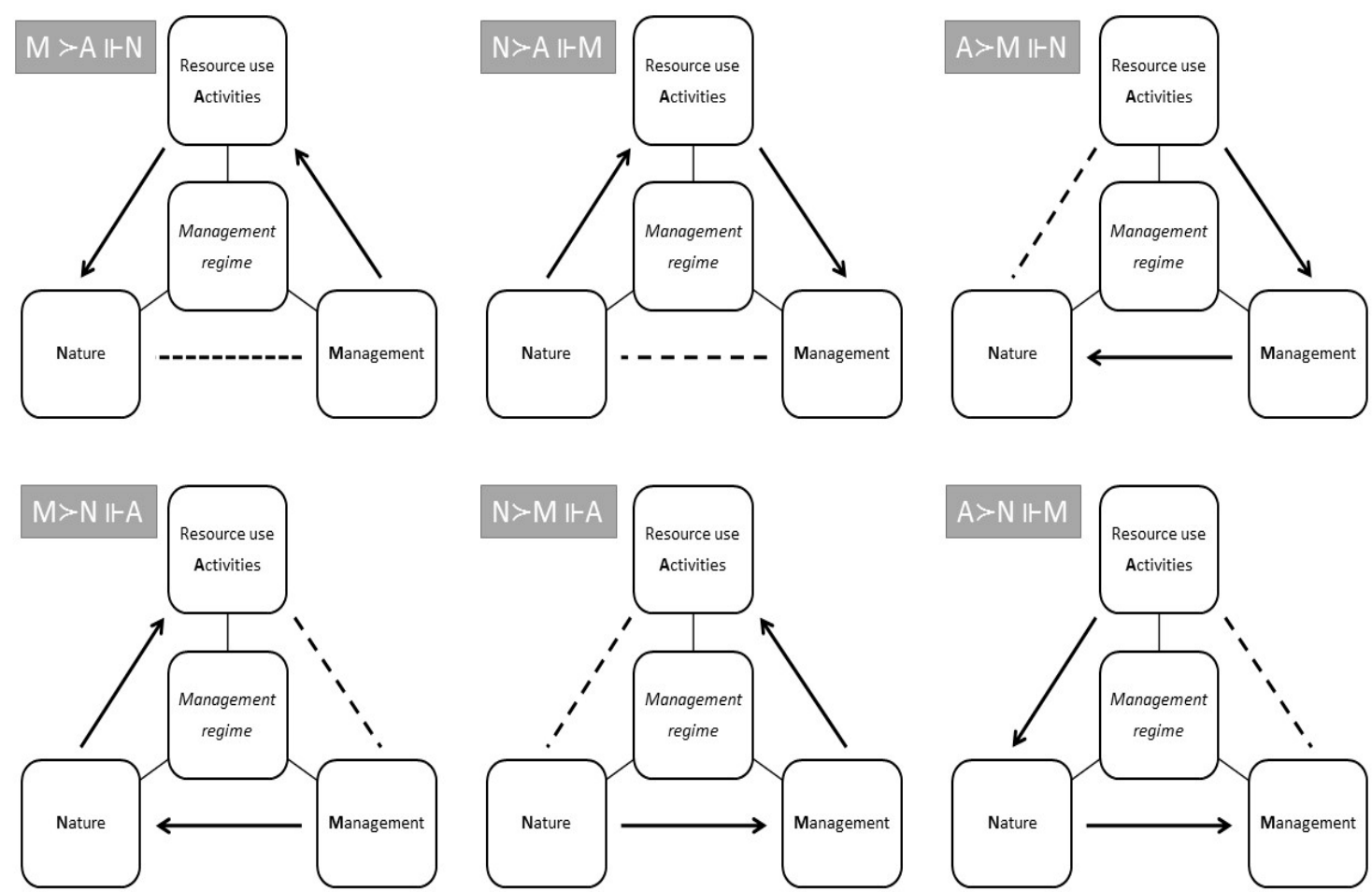

Figure 2. Six theoretical management regimes characterized by a social-ecological ontology defined with three building blocks (Management, Activity, and Nature).

A particular ontology of a management regime is understood according to the bi-directional relationships among its components. To fully account for the relationships among these components in terms that can describe patterns of relationality (i.e., state or condition of being related), we propose to use supra $(\succ)$ as an operator indicating a relational scheme (this formalism should not be understood as a mathematical or logical formalism but as a conventional and grammatical symbolism useful to depicted the different patterns of Figure 2). As such, the relation $X \succ Y$ indicates a relational scheme or set, depicting the co-existence of $X$ and $Y$ in which $Y$ is dependent on $X$, i.e., $X$ is the 'driver' of $Y$. Thus, for example, an anthropocentric conceptualization of human-nature relationships can be symbolized by $\mathrm{A} \succ \mathrm{N}$. Conversely, a biocentric conceptualization would be written as $\mathrm{N} \succ \mathrm{A}$. However, the dependency relationship is insufficient to account for the specific dynamics of a given social-ecological system. We need a third relationship that depicts integration and enablement. For instance, the management of a protected area cannot be understood in terms of the prevalence given to one component or another but only as the integration of this prevalence into the management. We suggest the operator $\Vdash$ to designate this integration as a process. Thus, the management $(\mathrm{M})$ of a natural area shaped by the prevalence of a human activity $(\mathrm{A})$ on a natural system $(\mathrm{N})$ can be described as the trilateral relationship $\mathrm{A} \succ \mathrm{M} \mid \Vdash \mathrm{N}$. This statement can also be read as management (M) integrates the relational existence of $\mathrm{A} \succ \mathrm{N}$.

The combination of the three terms allows us to describe six theoretically possible management regimes that are based on their effective interactions in a coastal management plan (Table 1). As seen in this table, a given type of management policy (e.g., managed retreat) may be related to several management regimes. Each of these regimes can coexist and relate to different temporal and spatial scales. In contrast, diverse types of management policies that claim to be radical alternatives in fact may correspond to the same management regime. 
Table 1. Examples of six theoretical management regimes to explore adaptation to global change in coastal areas.

\begin{tabular}{|c|c|c|c|c|}
\hline Ontology & Description & $\begin{array}{l}\text { Hypothetical Example to } \\
\text { Illustrate the Ontology }\end{array}$ & $\begin{array}{l}\text { Example of Biodiversity Conservation } \\
\text { in Coastal Wetlands }\end{array}$ & Example of Coastal Management \\
\hline $\mathrm{N} \succ \mathrm{M} \Vdash \vdash \mathrm{A}$ & $\begin{array}{l}\text { Activity contingent on } \\
\text { Management determined by } \\
\text { Nature }\end{array}$ & $\begin{array}{l}\text { Duck hunting in } \\
\text { temporary-flooded natural } \\
\text { marshes }\end{array}$ & $\begin{array}{l}\text { Aiguamolls de l'Empordà Natural Park } \\
\text { (Spain): water management in nature } \\
\text { reserves for biodiversity purposes }\end{array}$ & $\begin{array}{l}\text { Ebro delta (Spain): Ecotourism based on a } \\
\text { managed retreat implemented to conserve } \\
\text { biodiversity }\end{array}$ \\
\hline $\mathrm{A} \succ \mathrm{M} \Vdash \vdash \mathrm{N}$ & $\begin{array}{l}\text { Nature contingent on } \\
\text { Management determined by } \\
\text { Activities }\end{array}$ & $\begin{array}{l}\text { Creation and management of a } \\
\text { pond for duck hunting } \\
\text { purposes }\end{array}$ & $\begin{array}{l}\text { Camargue Biosphere Reserve (France): } \\
\text { human-made nature such as hunting } \\
\text { marshes with water level management } \\
\text { and pond creation }\end{array}$ & $\begin{array}{l}\text { Western Scheldt estuary (The Netherlands) } \\
\text { Loss of intertidal habitats because of } \\
\text { dredging, and seaward move to hold the } \\
\text { line to protect human activities and river } \\
\text { transportation facilities }\end{array}$ \\
\hline $\mathrm{N} \succ \mathrm{A} \| \mathrm{M}$ & $\begin{array}{l}\text { Management contingent on } \\
\text { Activity determined by Nature }\end{array}$ & $\begin{array}{l}\text { Land management by salt or } \\
\text { tourism industries located on } \\
\text { sea shores }\end{array}$ & $\begin{array}{l}\text { Mekong delta region (Vietnam): } \\
\text { reinforced natural determinism such as } \\
\text { salt industry development locations or } \\
\text { fish farms }\end{array}$ & $\begin{array}{l}\text { Danube Delta (Romania): Managed retreat } \\
\text { or holding the line with dikes for a tourism } \\
\text { industry dependent on sand beaches }\end{array}$ \\
\hline $\mathrm{M} \succ \mathrm{A} \Vdash \vdash \mathrm{N}$ & $\begin{array}{l}\text { Nature contingent on Activity } \\
\text { determined by Management }\end{array}$ & $\begin{array}{l}\text { Marshes created by traditional } \\
\text { irrigation systems that drive } \\
\text { modern agricultural } \\
\text { development }\end{array}$ & $\begin{array}{l}\text { Nile delta region (Egypt): specific } \\
\text { farming and traditional irrigation } \\
\text { systems or agro-environmental policies }\end{array}$ & $\begin{array}{l}\text { Messolonghi Lagoon (Greece): } \\
\text { conservation of the wetlands based on the } \\
\text { protection of fisheries and salt extraction by } \\
\text { building groynes to hold the line }\end{array}$ \\
\hline $\mathrm{A} \succ \mathrm{N} \Vdash \mathrm{M}$ & $\begin{array}{l}\text { Management contingent on } \\
\text { Nature determined by Activity }\end{array}$ & $\begin{array}{l}\text { Agro-environmental } \\
\text { management plan for wet } \\
\text { meadows depending of } \\
\text { mowing or grazing activities }\end{array}$ & $\begin{array}{l}\text { Ronde Hoep Polder (The Netherlands): } \\
\text { grassland mowing and grazing, Nature } \\
\text { conservation of human-made wetlands }\end{array}$ & $\begin{array}{l}\text { Beach Management Assistance Program } \\
\text { (Florida): Accommodations to manage sea } \\
\text { erosion by sand additions or beach } \\
\text { restoration to protect housing areas }\end{array}$ \\
\hline $\mathrm{M} \succ \mathrm{N} \Vdash \mathrm{A}$ & $\begin{array}{l}\text { Activity contingent on Nature } \\
\text { determined by Management }\end{array}$ & $\begin{array}{l}\text { Tourism activity based on } \\
\text { Biodiversity increased by an } \\
\text { ecological restoration plan }\end{array}$ & $\begin{array}{l}\text { Management of wetlands along the Gulf } \\
\text { of Finland migratory flyway (Finland): } \\
\text { pasture development based on ecological } \\
\text { restoration and management for } \\
\text { biodiversity purposes }\end{array}$ & $\begin{array}{l}\text { Camargue (France): Human activities } \\
\text { depending on natural process dynamics } \\
\text { due to abandonment of former salt pans } \\
\text { and managed retreat }\end{array}$ \\
\hline
\end{tabular}


This trilateral formalized relationship is critical to understand the adaptation and resilience of a social-ecological system (SES), $[21,30,31]$ to climate change because it distinguishes between two levels of change.

Within each management regime, the nature of each term may change, and the relationship intensity may increase or decrease. However, this change is only internal. The management regime structure may not change, because the adaptive capacity of the whole depends on the element (A, $M$ or $N$ ) to which prevalence is given. For example, in the case of $A \succ N \vdash M$, the adaptation of Activities (A) largely drives the resilience of the other terms, and a change in management is unlikely to restore the state of the entire area if an impact occurs. A change in the adaptability of all three terms from a change in management goals and practices is possible only through a change of management regime, because of the asymmetry of the relationship, which leads, for instance, to $\mathrm{M} \succ \mathrm{A} \Vdash \mathrm{N}$.

A great diversity of sociological, political and economic factors and processes can contribute to this management regime change. Our aim is not to identify these factors here but only to illustrate the need to distinguish among these different levels of adaptation. Overall, producing a set of management regime combinations would enable a given group of decision makers to question the social-ecological ontology and the different adaptive trajectories that result from the different relationalities that emerge in the management of a SES. Here we focus on three examples (that were well studied by both social and ecological sciences) to illustrate how ontologies changed with the social-ecological trajectory of the SES and in turn how the SES changed or not the dominant ontology according time. The analysis of the case studies is based on different sources: PhD thesis, postdoctoral and long-term study sites of some authors (RM, LN, AA, VM), content analysis of various policy documents, and workshop or stakeholder interviews, including strategic decision makers representing the main private and public organizations in the context of three research projects (see acknowledgements). We illustrate this process of management regime shifts and re-combinations in three case studies of the Camargue Biosphere Reserve on the Rhone River delta in southern France, the Danube Biosphere Reserve on the Danube River delta in Romania and the Garden Route National Park and Biosphere Reserve in South Africa.

\section{Management Regime Shifts in the Camargue Biosphere Reserve in Southern France}

This example illustrates the progression from a SES dominated by $\mathrm{A} \succ \mathrm{N} \Vdash \mathrm{M}$ ontology with specific areas where human activities and management where determined by nature to a balance of high diversity of ontologies, contributing to move from a land sparing to a land sharing approach in both the understanding and management of the SES.

The Camargue encompasses c. 150,000 ha of the Rhone River delta. It is a wetland of international importance regarding water birds (i.e., a Ramsar site), a regional natural park and a UNESCO world biosphere reserve. Different types of freshwater and brackish marshes and lagoons cover a total surface area of c. 60,000 ha. Land-use changes associated with economic development during the past century have had negative effects on wetlands, mainly through drainage, inappropriate water level regimes or eutrophication [32].

The Camargue landscape is often described as being shaped by land use conflicts which are themselves affected by the physical configuration of the landscape and environmental constraints [33].

Before the 1970s, the landscape changes were initially based on human activities that intentionally and unintentionally produced novel ecosystems and water management regimes. The logic was largely anthropocentric, and the main activities manipulated natural landscapes to meet human needs rather than adapt to ecological changes (i.e., adapting to the high spatial and temporal variability of the rain and floods of the Mediterranean climate). During this period, we observed a number of regimes of relations that fit the management regime of $\mathrm{A} \succ \mathrm{N} \Vdash \mathrm{M}$, and where " $\mathrm{A}$ " was rice farming, wine production, salt production, duck hunting, and bull and horse breeding, " $\mathrm{N}$ " was Mediterranean 
wetlands and " $\mathrm{M}$ " was landscape manipulation through technology (Table 2). During this period, the environment was managed for the benefit of human activities and not to conserve biodiversity.

However, in the early 20th century, for various reasons well described by [34], two identical ontologies began to conflict, such that $A_{R} \succ N_{R} \Vdash M_{R}$ and $A_{S} \succ N_{S} \Vdash M_{S}$, where " $A_{R}$ " is rice farming and "As" is salt production (Table 2). Fresh water, pumped into the system by rice farmers, started inundating salt pans. Existing drainage networks were not designed to cope with this change and were too costly to re-build.

Table 2. The changing frames of the integration of human activities and nature conservation in the Camargue Biosphere Reserve (France).

\begin{tabular}{|c|c|c|c|c|c|c|}
\hline & $\begin{array}{l}\text { Approximate } \\
\text { Timeline }\end{array}$ & $<1970$ & 1970-1980 & 1980-2000 & 2000-2010 & $>2010$ \\
\hline & $\begin{array}{c}\text { Framing of } \\
\text { Biodiversity } \\
\text { conservation } \\
\text { from [35] }\end{array}$ & $\begin{array}{c}\text { Spatial } \\
\text { segregation }\end{array}$ & Pre-integration & Integration & Hyper-integration & Post-integration \\
\hline & $\begin{array}{l}\text { Key ideas } \\
\text { adapted } \\
\text { from [22] }\end{array}$ & $\begin{array}{c}\text { Species, } \\
\text { Wilderness, } \\
\text { Protected } \\
\text { areas, } \\
\text { Nature } \\
\text { conservation }\end{array}$ & $\begin{array}{c}\text { Extinction, } \\
\text { Threatened } \\
\text { species, Habitat } \\
\text { loss, Pollution, } \\
\text { Overexploitation } \\
\text { Natural resource } \\
\text { management }\end{array}$ & $\begin{array}{l}\text { Ecosystems, } \\
\text { Ecosystem } \\
\text { approach, } \\
\text { Integrated } \\
\text { management, } \\
\text { Biodiversity } \\
\text { conservation }\end{array}$ & $\begin{array}{c}\text { Ecosystem } \\
\text { services, } \\
\text { Environmental } \\
\text { changes, } \\
\text { Economic values, } \\
\text { Resilience, } \\
\text { Social-Ecological } \\
\text { Systems }\end{array}$ & $\begin{array}{c}\text { Global } \\
\text { changes, } \\
\text { Cultural } \\
\text { values, } \\
\text { Adaptation, } \\
\text { Transformation, } \\
\text { Care and } \\
\text { responsibility } \\
\text { for nature }\end{array}$ \\
\hline \multirow{6}{*}{ 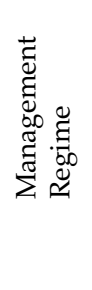 } & $\mathrm{M} \succ \mathrm{N} \| \mathrm{A}$ & & & & & $x$ \\
\hline & $\mathrm{M} \succ \mathrm{A} \| \mathrm{N}$ & & & $x$ & $x$ & $x$ \\
\hline & $\mathrm{A} \succ \mathrm{N} \mid \vdash \mathrm{M}$ & $x$ & & $x$ & $x$ & $x$ \\
\hline & $\mathrm{A} \succ \mathrm{M} \Vdash \mathrm{N}$ & & $x$ & $x$ & $x$ & $x$ \\
\hline & $\mathrm{N} \succ \mathrm{M} \Vdash \mathrm{A}$ & $x$ & $x$ & & $x$ & $x$ \\
\hline & $\mathrm{N} \succ \mathrm{A} \| \mathrm{M}$ & $x$ & $x$ & $x$ & $x$ & $x$ \\
\hline
\end{tabular}

The relationships subsequently became $\mathrm{N} \succ \mathrm{A} \Vdash \mathrm{M}$. The salt industry joined a coalition with a conservation NGO whose interaction management followed a different principle in which $\mathrm{N} \succ \mathrm{M} \Vdash \mathrm{A}$ [36]. The end of this major land use conflict occurred through a change in social-ecological ontology through an alliance with an actor that was shaped in another principle relationship among A, $\mathrm{M}$ and $\mathrm{N}$. The result was a significant change: the importance of one management regime $(\mathrm{N} \succ \mathrm{M} \Vdash \mathrm{A})$ with greater recognition of the conservation NGO and the creation of a nature reserve in the lagoon system that was formerly used to pre-concentrate salt increased significantly (Table 2).

Another major change— the appearance of the $\mathrm{A} \succ \mathrm{M} \Vdash \mathrm{N}$ management regime—occurred in the early 1970s with the creation of a regional natural park [34]. Because the park was initially created as a tool for integrated development planning and to support human activities, this support should have resulted in favorable landscape and sustainable natural resource management. With the ecological modernization of the 1990s and 2000s, the park authorities focused more on nature protection and adopted an $\mathrm{N} \succ \mathrm{M} \Vdash \mathrm{A}$ management regime for managing many acquired land estates to conserve biodiversity and to adapt to climate change, without generating local social conflicts [32,33]. Since 2010, the southern part of the Rhone River delta has undergone a major transformation and currently hosts the largest ecological restoration site in Europe, with approximately 6000 ha of former salt pans abandoned because of the effects of the 2008 financial crisis on the salt industry and the development of a retreat plan to adapt to rising sea levels and consequent coastal erosions and sea floods [37].

Until recently, biodiversity conservation management in the Camargue and its ecological modernization and articulation with climate-change adaptation plans did not lead to the dominance of a single management regime; instead, this process led to a diversification of ontologies that coexisted 
alongside historical changes (Table 2, [38]). Over the past 55 years, the dominant view of biodiversity integration in development projects has changed several times and has resulted in, for example, a shift in emphasis from ecosystem management to social-ecological system dynamics. No framings or ideas have disappeared as new ones have arisen, thus resulting in multiple ontologies currently in action. This result suggests that a key to social-ecological resilience to climate change and more generally, to global changes, may lie in the diversification of ontologies. This finding also indicates the need for reassessment of all dual and binary (either-or) oppositions between hard shoreline protection and ecological engineering or nature-based adaptation $[3,5,6]$.

The Camargue has thus far been resilient to economic shocks and river and sea flooding ${ }^{13}$. Despite major land upheavals since the 17th century, this SES has shown a marked ability to adapt to changes in policy and agricultural markets [32]. A multidisciplinary literature review (comprising history, law, geography, ecology, sociology, and management) has highlighted the crucial role of the diversity of uses and institutions that have allowed this SES to weather the effects of economic crises and environmental hazards since the late 19th century [38].

Despite increasing hydraulic specialization, many factors have prevented an exclusive land conquest by a dominant human activity. These factors are (i) the natural constraints; (ii) local stakeholders that have an income from outside the delta; and (iii) the cultural identity and territorial roots and traditions that reinforce the notion of the Camargue as wild and remote wetlands supporting the breeding of white horses and black bulls. Many land uses have been maintained over time, thus allowing for differential management that buffers the negative effects of global change and can act as a source of future innovations. The role of minority actors, who against all odds continue their activities, customs and practices, has also contributed to maintaining the diversity of land uses [33].

Although diverse contrasting ontologies exist in the Camargue, new threats from unexpected sources are however emerging. The recent emergence of what we refer to as a hyper-owner: the French Coastal Protection agency (Conservatoire du littoral) who owns most of the protected areas of the delta that cover c. $22 \%$ of the delta' surface area, including the former salt pans. The primary purpose of this agency, conservation of nature, raises questions about the impact of this major land use change on the adaptive capacity of the Camargue in relation to global changes (such as EU common agricultural policy, climate, and floods). This public policy could even negatively affect the resilience of the Camargue.

\section{Management Regime Shifts in the Danube Biosphere Reserve in Romania}

This example illustrates how the ontology helps us better understand the emerging hyper-integration process following a change from a SES dominated by $\mathrm{A} \succ \mathrm{N} \Vdash \mathrm{M}$ ontology with a hyper-segregation driven by economic development and then by $\mathrm{N} \succ \mathrm{M} \Vdash \mathrm{A}$ with another form of hyper-segregation but driven by nature protection.

The Danube Delta is by far the largest wetland of the European Union (covering c. 415,000 ha) and one of the less impacted by hydraulic engineering and human activities [39]. Despite intensive landscaping carried out between the 1970s and the 1980s on the Danube Delta territory, the region is recognized by UNESCO as the "most natural" delta in Europe [40], encompassing the largest swamp area of the continent. Depending on the hydrological regime, water covers $80-90 \%$ of the total delta area and directly impacts the economic and social development opportunities in the region (fishing areas are much more important than agriculture land, and vary between 170,000 and 270,000 ha).

The management of this huge, isolated and underexploited area [41] passed over time from the "extreme productivism" (i.e., massive State investments in order to better valorize the economic potential, without any concern about nature) to "extreme conservation" (strict protection of natural potential and exclusion of local populations). If the area is today one of the most important natural heritage sites in Europe [39], both components of Danube Delta socio-ecological system are threatened and its capacity for adaptation and resilience is undermined by exclusion and week participation of locals into conservation management. 
At the beginning of the 20th century Danube Delta was mostly a pristine wetland. The only important human intervention in the delta landscape was the hydrological engineering undertaken by the European Commission of the Danube (between 1858 and 1912) in order to ensure the navigation of large vessels on the main Danube arm (Sulina) to the Black Sea. In this huge flooding area, the agricultural areas were only about 6400 ha (1.5\% of the total area) in 1938, protected by small containments created by local populations for subsistence agricultural land. An important fishing activity was the base of the local economy, with very week control from the central state and the development of intensive practices of fishing [41]. This situation evolved at the end of the 19th century, when was introduced the first modern legislation on fishing and was created the Danube Delta Fisheries and Land Improvements Agency. During the next fifteen years, the increasing of delta fisheries productivity was realized with minor interventions over delta's ecosystem and hydrography. Grigore Antipa [42], a Romanian scientist in charge with the design of fishery administration in Danube Delta considered that the economic activity must be concordant with the natural environment specificity. During this period, the Danube Delta was administrated by this organization in a $\mathrm{N} \succ \mathrm{A} \Vdash \mathrm{M}$ configuration, where " $\mathrm{N}$ " is the Danube Delta ecological and hydrological system, " $\mathrm{A}$ " is fishing activity and " $\mathrm{M}$ " is the fishing management by the administration. The fishing was therefore the perfect way for the local population to adapt to the natural environment: "The natural regime of the Danube water flow does not require major containment works because it corresponds to the principles of modern fish farming which organizes production in several basins according to the age and needs of the fish" ([42], p. 102).

Another mechanism for controlling fishing activities so as to not exceed the renewable capacity of the ecosystem was the introduction of fishing rights (fishing licenses, prohibition areas and periods, prohibition of very damaging fishing tools and practices, etc.). Fishing activities as an adaptation strategy to environmental degradation were in a $\mathrm{N} \succ \mathrm{M} \Vdash \mathrm{A}$ ontology, as fishing rights (" $\mathrm{M}$ ") were defined in order to correspond to environmental constraints, but the integration of $\mathrm{N}$ and $\mathrm{M}$ were done during the fishing activity itself at the very local level of fishing activity.

During this period, without any link with fishing activity development, the first protected area in the Danube Delta (the second protected area in Romania) was created [43]. Letea forest with its 5200 ha was declared "monument of nature" in 1938 by the Romanian Academy, for ecological reasons (originality of the species: a mixture of oak, ash, alder and climbing lianas) as well as for aesthetical ones (conservation of the landscape made of marine sand dunes and forest vegetation). In this conservation case, we were in a $\mathrm{N} \succ \mathrm{M} \Vdash \mathrm{A}$ ontology, with a spatial segregation between economic area and protected area (Table 3). This model of conservation based on spatial segregation was enlarged to the whole area after 1990 when a UNESCO Biosphere Reserve split in three protection areas was created [43].

Between 1945 and 1989, the Danube delta was for almost 45 years under a different management regime, dominated by huge polderization programs aimed to develop agriculture and fishing farms, under the strong intervention of the communist administration. During this period, the management regime was characterized by a mix of $\mathrm{M} \succ \mathrm{A} \Vdash \mathrm{N}$ or $\mathrm{A} \succ \mathrm{N} \Vdash \mathrm{M}$ ontologies. A pharaonic landscaping program envisaged 244,000 ha (including 144,000 ha of wetlands), for planned agricultural development, fisheries and forestry [44]. Until the end of 1989, 100,000 ha were dammed and drained or not anymore connected to the natural hydrography system [44]. Massive physical transformations of the environment through damming, channeling, the creation of polders, and the intensive activities led to pollution, biological perturbations (provoked by escapement of alien fish species form the fishing farms into the natural environment), the decline of fish populations and even the disappearance of certain species [45]. The human control over the nature imagined by the communism management regime has been both an ecological and social failure [43]. The landscaped area lost its biodiversity directly related with the flooding regimes and became very few resilient, as depending on continuous human investments. The productivity levels imagined by the State services never reached the planed level and lead to economical breakdown. 
Table 3. The changing frames of the integration of human activities and nature conservation in the Danube Delta Biosphere Reserve (Romania).

\begin{tabular}{|c|c|c|c|c|c|c|}
\hline & $\begin{array}{c}\text { Approximate } \\
\text { Timeline }\end{array}$ & $\begin{array}{l}\text { First Half of } \\
\text { the 20th } \\
\text { Century }\end{array}$ & 1945-1989 & 1990-1997 & 1997-2010 & $>2010$ \\
\hline & $\begin{array}{c}\text { Framing of } \\
\text { Biodiversity } \\
\text { conservation } \\
\text { adapted from } \\
{[22,35]}\end{array}$ & $\begin{array}{c}\text { Spatial } \\
\text { segregation }\end{array}$ & $\begin{array}{c}\text { Hyper-segregation } \\
1 \text { (driven by } \\
\text { economic } \\
\text { development) }\end{array}$ & $\begin{array}{c}\text { Hyper- } \\
\text { segregation } \\
2 \text { (driven by } \\
\text { Nature } \\
\text { Protection) }\end{array}$ & Integration & Hyper-Integration \\
\hline & Key ideas & $\begin{array}{l}\text { Hydrological } \\
\text { engineering } \\
\text { Fishing rights } \\
\text { Protected } \\
\text { areas }\end{array}$ & $\begin{array}{c}\text { Polderization } \\
\text { Habitat loss, } \\
\text { Pollution, } \\
\text { Extinction } \\
\text { Protected areas }\end{array}$ & $\begin{array}{c}\text { Protected } \\
\text { areas, } \\
\text { Nature } \\
\text { conservation } \\
\text { Ecological } \\
\text { restoration } \\
\text { Natural } \\
\text { resource } \\
\text { management } \\
\text { Ecosystem } \\
\text { approach } \\
\text { Biodiversity } \\
\text { conservation }\end{array}$ & $\begin{array}{c}\text { Economic } \\
\text { values, } \\
\text { Resilience, } \\
\text { Social-Ecological } \\
\text { Systems } \\
\text { Over-exploitation, } \\
\text { Threatened } \\
\text { species, } \\
\text { Ecosystem } \\
\text { services, } \\
\text { Environmental } \\
\text { changes }\end{array}$ & $\begin{array}{l}\text { Fishermen } \\
\text { associations, } \\
\text { Care and } \\
\text { responsibility } \\
\text { for nature, } \\
\text { Eco-tourism, } \\
\text { Cultural values, } \\
\text { Adaptation, } \\
\text { Integrated } \\
\text { management }\end{array}$ \\
\hline \multirow{6}{*}{ 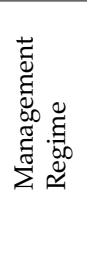 } & $\mathrm{M} \succ \mathrm{N} \Vdash \mathrm{A}$ & & $x$ & $x$ & $x$ & $x$ \\
\hline & $\mathrm{M} \succ \mathrm{A} \Vdash \mathrm{N}$ & $x$ & $x$ & & & $x$ \\
\hline & $\mathrm{A} \succ \mathrm{N} \| \mathrm{M}$ & & & & & \\
\hline & $\mathrm{A} \succ \mathrm{M} \Vdash \mathrm{N}$ & & $x$ & & $x$ & $x$ \\
\hline & $\mathrm{N} \succ \mathrm{M} \Vdash \mathrm{A}$ & $x$ & & $x$ & $x$ & $x$ \\
\hline & $\mathrm{N} \succ \mathrm{A} \Vdash \mathrm{M}$ & $x$ & & $x$ & $x$ & $x$ \\
\hline
\end{tabular}

Even if in the 1970s, the protected area in Danube Delta increased to 35,000 ha, this was no effective protection on the ground since no administration was appointed to manage these areas [41]. We can qualify this period as a hyper-segregation period. On one side, we observe the imposition of a productivist economy, based on the ideology of the "total control over Nature". On another side, we observe the spatial expansion of the protected area in places with no obvious economic interests (Table 3).

Immediately at the end of the communism, the Danube delta felt into another major social crisis, when the Danube Delta Biosphere Reserve was created in 1990. This radical change was possible by a complex institutional and territorial reconfiguration aiming to eradicate the traces and the vestige of the precedent management regime [46]. This social-ecological transition, imposed Nature as a driving element in a first period (1990-1997) but give very few considerations to the integration of human activities. All the State productive investments into the area were stopped, as well as the landscaping works still on the run. The Biosphere Reserve (BR) covers the entire Danube delta and a large lagoon area situated in the Southern part of delta, summing 580,000 ha. On the BR's territory, 50,904 hectares were declared strictly protected areas, where economic activities are forbidden. Huge programs of ecological restoration by flooding abandoned polders were rapidly successful, but all the local activities were totally neglected by the new BR's management regime in its early period [47]. After 1997 a fishing legislation was introduced and was continuously adapted in the next years, as a way of protecting and managing Nature, leading to change the management regime of the BR. Many conflicts occurred in the early 2000s between the BR' management agency (i.e., a central State institution with very few local stakeholders' participation) and fishermen denouncing too many constraints on fishing activity and their exclusion from the management body [46]. It is only after 2007, when Romania joined the European Union that fishermen organizations started to participate in fishing management and to benefit from European funds for sustainable development of fishing communities, mixing cultural values with economic and environmental issues [46]. 
To sum-up, the social-environmental history of Danube Delta is marked by discontinuities and radical shifts of management regimes. The resilience of the Danube delta ecosystem was endangered each time strong central State institutions tried to impose one single management regime, either having the economy as a driving force, either imposing Nature as a priority face to local social issues. The difficulties of maintaining a single Nature domination-based management regime ( $\succ \mathrm{A} \Vdash \mathrm{M}$ or $\mathrm{N} \succ \mathrm{M} \vdash \mathrm{A}$ ), after the creation of the BR, and the multiplication of intervention areas and management actions (e.g., protected areas' management and control, ecological restoration plans, fishing rights management, integration of local identities and place attachment rising issues, etc.), show that a single management regime does not build social-ecological resilience over time.

\section{Management Regime Shifts in the Garden Route, South Africa}

This example illustrates how the ontology can elucidate transformative shifts from nature exploitation activities to nature restoration activities. Diverse ontologies may enhance the resilience of the SES.

South Africa's Garden Route Biosphere Reserve, a narrow east-west strip of coast between the escarpment of the Cape Fold Mountains and the Indian Ocean, stretches from Stilbaai in the south-west to Tsitsikamma in the north-east-a distance of about $280 \mathrm{~km}$. In addition to coastal forests, the dominant vegetation, Fynbos, is the subject of a World Heritage site (the Cape Floral Kingdom) and includes many endemic, rare and endangered plant species. The Garden Route Biosphere Reserve, approved by UNESCO in 2017, includes three Marine Protected Areas, various smaller provincial and local authority protected areas, with the Garden Route National Park at its core. Six World Heritage archaeological sites found along the Garden Route provide unique evidence of the earliest known use of tools by modern humans, dating back 160,000-170,000 years. Nowadays the Garden Route landscape is characterized by ribbon tourism development along the coast, cultivated plateau and mountain slopes covered by Fynbos scrubland interspersed with indigenous mountain and coastal forests and Pinus and Eucalyptus forestry plantations. Watersheds between the mountains and the coast are mostly small and steep. Large stands of invasive exotic plants in particular Australian Acacias such as $A$. cyclops and A. mearnsii constitute a major threat for the endemic biodiversity and threaten the sustainability of water resources.

The area has great tourism potential and for that reason development and population growth have increased rapidly over the past decades. Development intensifies on the coast, around the many estuaries that crisscross the area, as well as on the urban edges where infrastructure development proliferates to satisfy the growth needs of a society still marked by economic and social inequalities [39]. The Garden Route is also vulnerable to climate change which threatens ecological and human made infrastructures, biodiversity, water security, agriculture and forestry through more frequent and more intense droughts, floods and fires [48].

From the late 1700s up to the late 1940s, the Garden Route was mostly exploited for its timber resources extracted from indigenous Afromontane forest. State Forests were proclaimed in 1811 to protect forests for meeting the timber needs of the British Navy; subsequent proclamations were in Fynbos areas identified for afforestation with exotic trees [49]. Hence the emergence of nature protection in the 1900s was guided by an $\mathrm{A} \succ \mathrm{N} \Vdash \mathrm{M}$ pre-industrial ontology. In the early 1910s, some 340,000 ha of the Swartberg and Langeberg mountains (the future Gouritz Cluster Biosphere Reserve) were proclaimed specifically for the protection of water resources. The realization of water scarcity resulted in catchment management and protection; a $\mathrm{N} \succ \mathrm{A} \Vdash \mathrm{M}$ ontology emerged as the concerns about the impact of timber exploitation on water provision services started to rise. Further proclamation of State Forests as catchment areas occurred between 1920 and 1930. The 1930s were marked by the creation of the Addo Elephant National Park beyond the eastern end of the Garden Route. As [49] point out, the guiding principle was that South Africa's national parks should be accessible, adequately protected crown land that a growing urbanized population could utilize as amenities for both pleasure and education, with little consideration for ecological functions and processes. The farming and 
tourism industry took off in the mid-1900s, with the construction of the George to Knysna railway line inaugurated in 1928 and the N2 national highway, which reached the small town of Wilderness in 1952. Land transformation occurred in an $\mathrm{A} \succ \mathrm{N} \Vdash \mathrm{M}$ configuration, where the activities of resource users radically changed the nature and functions of the landscape [50], (Table 4). At the same time, researchers and conservationists started documenting the rate of decline of and threats to biodiversity and influencing policy makers and politicians of the former 'apartheid' government [49]. An $\mathrm{A} \succ \mathrm{N} \Vdash \mathrm{M}$ ontology emerged; the Department of Forestry closed the forests to all exploitation from 1940 to 1964 and the focus of the Department shifted to the establishment and management of plantations of exotic timber trees [51].

Table 4. The changing frames of the integration of human activities and nature conservation in the Garden Route (South Africa).

\begin{tabular}{|c|c|c|c|c|c|}
\hline & & $<1983$ & $>1983-1994$ & 1994-2010 & 2010-2017 \\
\hline & $\begin{array}{c}\text { Framing of } \\
\text { Biodiversity } \\
\text { conservation from } \\
{[22,35]}\end{array}$ & $\begin{array}{l}\text { Pre-integration. } \\
\text { Land } \\
\text { transformation and } \\
\text { exploitation for } \\
\text { urban } \\
\text { development, } \\
\text { forestry and } \\
\text { agriculture. } \\
\text { Ignorance about } \\
\text { coastal dynamics } \\
\text { and natural } \\
\text { infrastructure }\end{array}$ & $\begin{array}{l}\text { Spatial Segregation } \\
\text { Command \& } \\
\text { control } \\
\text { conservation } \\
\text { Separate } \\
\text { development with } \\
\text { forced removals. }\end{array}$ & $\begin{array}{l}\text { Integration } \\
\text { Integrated } \\
\text { Management. } \\
\text { expansion and } \\
\text { integration of } \\
\text { conservation estate, } \\
\text { legal protection } \\
\text { and integration. }\end{array}$ & $\begin{array}{l}\text { Hyper-integration } \\
\text { Integrated } \\
\text { development } \\
\text { planning for } \\
\text { tourism, climate } \\
\text { change adaptation, } \\
\text { economic } \\
\text { development and } \\
\text { job creation }\end{array}$ \\
\hline & Key ideas & $\begin{array}{l}\text { Over-exploitation. } \\
\text { Production. } \\
\text { Maximum yield. }\end{array}$ & $\begin{array}{c}\text { Economic } \\
\text { development over } \\
\text { conservation. } \\
\text { Protection. } \\
\text { Enforcement. } \\
\text { Threat } \\
\text { management. }\end{array}$ & $\begin{array}{c}\text { Biodiversity } \\
\text { conservation. } \\
\text { Systematic } \\
\text { conservation } \\
\text { planning. } \\
\text { Environmental } \\
\text { impact assessment. } \\
\text { Integrated } \\
\text { development } \\
\text { planning. }\end{array}$ & $\begin{array}{c}\text { Ecosystem services, } \\
\text { Economic values, } \\
\text { Resilience, Risk, } \\
\text { Adaptive } \\
\text { management, } \\
\text { Climate Change } \\
\text { Adaptation, } \\
\text { Cooperative } \\
\text { governance }\end{array}$ \\
\hline \multirow{6}{*}{ 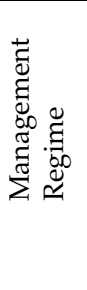 } & $\mathrm{M} \succ \mathrm{N} \Vdash \mathrm{A}$ & & $x$ & $x$ & $x$ \\
\hline & $\mathrm{M} \succ \mathrm{A} \| \mathrm{N}$ & & $x$ & $x$ & $x$ \\
\hline & $\mathrm{A} \succ \mathrm{N} \| \mathrm{M}$ & $x$ & $x$ & $x$ & $x$ \\
\hline & $\mathrm{A} \succ \mathrm{M} \Vdash \mathrm{N}$ & & & $x$ & $x$ \\
\hline & $\mathrm{N} \succ \mathrm{M} \Vdash \mathrm{A}$ & & & & $x$ \\
\hline & $\mathrm{N} \succ \mathrm{A} \| \mathrm{M}$ & $x$ & $x$ & $x$ & $x$ \\
\hline
\end{tabular}

This led to a proliferation of formally proclaimed protected areas in the Garden Route between 1964 and 1994, including a Ramsar site [51]. The dominant regime, $\mathrm{M} \succ \mathrm{N} \Vdash \mathrm{A}$, i.e., command and control conservation by the State emerged [49]. These new proclamations were also partly influenced by the apartheid government's desire to control people and implement its social engineering and racial segregation policies-a by-product of formal conservation [52]. Between the mid-1960s and 1990, 21 new coastal suburbs were developed along the Garden Route coast. These were mostly second homes used for holiday accommodation, but significantly (and permanently) affected the integrity of coastal dunes and their associated biodiversity which, until then, played a crucial role in protecting built infrastructure from storm surges [53]. The political driver was economic development to stimulate the struggling South African economy. While protected areas were conserving biodiversity (often at the cost of traditional livelihoods, [54]), and maintaining ecosystem services, ecological infrastructures were being rapidly eroded outside parks. 
With the advent of democracy in 1994, a series of transformative environmental and natural resource management policies and Acts were promulgated, notably the White Paper on National Environmental Management which paved the way for mandatory Environmental Impact Assessment regulations in 1997 and the National Environmental Management Act of 1998; the National Water Strategy and the accompanying National Water Act; the National Forestry Policy and National Forests Act; the National Environmental Management: Protected Areas Act of 2003; and the National Environmental Management: Biodiversity Act of 2004. Although an example of $\mathrm{M} \succ \mathrm{A} \Vdash \mathrm{N}$, these Acts also emphasized public participation and more equitable sharing of natural assets [55] $(\mathrm{A} \succ \mathrm{M} \Vdash \mathrm{N}) — \mathrm{a}$ backlash against the injustices of the previous era. Development became constrained by environmental impact assessment legislation, but this did not mean that the environment was always sustainably managed. Impact assessments were prone to politically motivated approvals, the capacity to enforce the legislation was severely constrained and many land users continued with unsustainable land use practices if they could avoid prosecution (Guerbois et al. in rev). The Garden Route National Park, an unfenced protected area which (unusually for South Africa) is embedded in a mosaic of other land uses, was officially gazetted in 2009. It encompasses the Wilderness Lakes RAMSAR site as well as the largest block of Afromontane forest in South Africa [51]. However, the lingering legacy of unsustainable ecosystem management practices of the previous era still continue to threaten biodiversity and ecosystem services in the Garden Route.

More recently (after 2010) there has been a resurgence of environmental stewardship and network governance (sensu [56]) initiatives in the Garden Route, spearheaded by concerned citizens rather than government [57]. This transformative shift towards activities that restored rather than exploited nature ( $\succ \mathrm{N} \Vdash \mathrm{M}$ ) is being prompted by greater awareness of the value of ecosystem services and the importance of biodiversity in maintaining these $(\mathrm{N} \succ \mathrm{M} \Vdash \mathrm{A})$ and fears about the risks imposed by climate change and general loss of ecological infrastructure. This transition is facilitated by social learning processes initiated by stakeholder's initiatives and consultative meetings around participatory catchment management, spatial development, coastal management and setback lines, as well as management of national parks and biosphere reserves. Participatory action research by universities and other research organizations, aimed at learning about sustainability [58], also played a role in accompanying the $\mathrm{N} \succ \mathrm{A} \Vdash \mathrm{M}$ transition. Many voluntary and citizen programs aimed at more sustainable living, for example biological farming, eco-labelling of farmed produce, pulp and timber, wind and solar energy initiatives, water saving initiatives, private conservancies, and invasive plant management programs, accompany the establishment of the Garden Route Biosphere Reserve. These $\mathrm{M} \succ \mathrm{N} \Vdash \mathrm{A}$ innovations have been spearheaded by civil society, supported and followed (but seldom lead) by government.

The move towards self-organized stewardship and ecological solidarity is set to continue with growing environmental awareness in the Garden Route, coupled with experiences of the realities of climate change such as floods, droughts and fires, cheaper renewable energy and growing social networks. The threats of growing inequality remain, however. Until this has been addressed through land reform, job creation, social programs and greater social cohesion the Garden Route's sustainability will remain in jeopardy. Nature could be the binding force that helps to bridge social divisions. This will however require strong and altruistic leadership: a rarity world-wide.

\section{Looking Forward}

Overall, these three case studies show that the MAN ontology helps better understand how different management regimes mix explanatory elements of change in human/environment interaction analysis and actions. It elucidates the feedbacks between different management regimes to explain changes in human-environment interactions. This social-ecological ontology adds a valuable layer of meaning to the IAD framework. Indeed, for example the biophysical context (influenced by A in our ontology), and rules-in-use (relates to $\mathrm{M}$ in our ontology) structure a repeated set of action situations, that instantiate the management regime that operates on a fast inner loop. The management regime 
may change whereby evaluative criteria are applied to each set of contextual factors. The way in which these are configured determines the structure of the action situation and how it operates. Our work suggests that there are, at a general level, 6 choices for the arrows that lead from contextual factors to action situations (i.e., $\mathrm{N} \succ \mathrm{M} \Vdash \mathrm{A}, \mathrm{M} \succ \mathrm{N} \Vdash \mathrm{A}$, etc.). Because the IAD is a framework, Ostrom and others were never explicit about these linkages. Our ontology is one way to put flesh onto the IAD skeleton. Moreover, another outcome from this work relates to feedback systems that are fundamental features of Social-Ecological Systems that operate on multiple time scales. Our ontology provides a way to talk about how the outer feedback loop is organized, and thus how the inner feedback loop (management or governance regime) operates.

The resulting MAN ontology can help identify similarities, complementarities and oppositions between different adaptation policies or management plans. It may also lead to a better understanding of historical management regime shifts, identify areas for scientific clarification, and explain the emergence of diverse management regimes, despite differences in historical trajectories. The survival of heterogeneous ontologies, notwithstanding prevailing dominant management regimes, could be a key process in the long term social-ecological resilience of a SES. An ontological approach seems useful to explore social-ecological dynamics and management regimes and to improve environmental history approaches by observing the diversity of ontologies and comparing them to theoretical ones.

Thus, this work raises two important implications for biodiversity conservation and climate adaptation research and policies. First, the case studies suggest that social-ecological resilience to global change may, at least in part, rest on the diversity of ontologies as it has been shown for biodiversity and functional diversity $[59,60]$ or institutional diversity $[24,25,61,62]$. Our ontology also elaborates the outcomes of the IAD framework. Many recent empirical works have been done to test whether the design principles actually work, or tell us anything about system resilience/performance (i.e., [63]). That is, are systems with more design principles more "successful"? Based on empirical works our study suggests that SESs with mixes of ontologies (i.e., mixing $\mathrm{A} \succ, \mathrm{M} \succ, \mathrm{N} \succ$ ) could be more resilient to global change while systems dominated by $\mathrm{A} \succ \mathrm{N} \Vdash \mathrm{M}$ or $\mathrm{A} \succ \mathrm{M} \Vdash \mathrm{N}$ ontologies are destined to fail. Further research, incorporating a larger database of case studies, should focus on these linkages and outcomes, to highlight appropriate governance structures with positive outcomes for people and biodiversity.

In a global context of decentralization and increasing public participation in the deliberations related to management decisions and the multiplication of land acquisitions for conservation or managed retreat purposes, there is an inconsistent but increasing risk of management intent homogenization (i.e., a Nature domination scheme with $\mathrm{N} \succ \mathrm{A} \Vdash \mathrm{M}$ or $\mathrm{N} \succ \mathrm{M} \Vdash \mathrm{A}$ ). Here, decision-makers might conflate intentional management with effective management (i.e., for example by being both public decision-maker and large landowner) and consequently reduce the diversity of ontologies by imposing one. These actions may become counterproductive and increase the vulnerability of the entire social-ecological system. A form of hyper-management that is implemented by nature conservationists in which all uses are linked to a single purpose (i.e., human/nature harmony) may lead to poor decisions and weak social compromises. Given the amount of information required to manage or control the system, this social-ecological agency may transfer both spatial and sectoral vulnerabilities, generate an increasing risk of a return to land sparing, and enhance natural hazards and social conflicts. The dominant pro-nature management intention can thus be counter-productive and fragile. A form of adaptive co-management would be a better way to develop a hyper-management approach [64].

Second, by providing an analytical framework with three building blocks (the nature or conditions of the ecological system, human activities and practices or management rules), we believe that researchers and policymakers' thoughts and discussions on adaptation would focus more on the process and ordering components than on results $[65,66]$. In addressing the adaptive management of complex systems such as conservation areas or coastal areas in response to climate change [2,67], we invite scientists, conservation and natural resource managers and policy makers to deal not 
only with social and environmental components but also with the place of nature in management regimes in local adaptation pathways [68] and policy processes in social-ecological systems [69]. Effective conservation planning and climate adaptation policy needs learning and greater emphasis on strategies that increase human values, knowledge and practices favorable to active adaptive management approach $[70,71]$. Social-ecological approaches to management regimes are part of the means to develop effective long-term adaptation.

Author Contributions: R.M., A.A., and L.N. contributed in preparation of original draft, conceptualization, data collection, selection of methodology, analysis, validation and investigation, review and edit the paper. V.M., C.G., C.F., J.M.A. contributed in data collection, analysis, validation, review and edit the paper.

Funding: This research was funded by French National Research Agency and the Belmont Forum and G8 International Opportunities Fund (IOF 2013) and Ministère de l'Écologie, du Développement Durable et de l'Énergie (France): Programme LITEAU 2013. C.G. and C.F. were supported the National Research Foundation of South Africa (Grant Number 86974).

Acknowledgments: The research presented in this paper contributes to the Camargue Adaptation Research Project (CAMADAPT) funded by the French Ministry of Ecology, and the research project "Multi-scale adaptations to global change and their impacts on vulnerability in coastal areas" (MAGIC), funded by the French National Research Agency and the Belmont Forum and G8 International Opportunities Fund (IOF 2013). V.M. was funded by the Global Environment Facility Program (Danube Delta Biodiversity Project-Local Benefits Case Studies, 2005). We thank two anonymous referees for challenging comments.

Conflicts of Interest: The authors declare no conflict of interest.

\section{References}

1. Jones, H.P.; Hole, D.G.; Zavaleta, E.S. Harnessing nature to help people adapt to climate change. Nat. Clim. Chang. 2012, 2, 504-509. [CrossRef]

2. Hill, C. Coastal infrastructure: A typology for the next century of adaptation to sea-level rise. Front. Ecol. Environ. 2015, 13, 468-476. [CrossRef]

3. Cheong, S.M.; Silliman, B.; Wong, P.P.; Van Wesenbeeck, B.; Kim, C.K.; Guannel, G. Coastal adaptation with ecological engineering. Nat. Clim. Chang. 2013, 3, 787-791. [CrossRef]

4. Adger, W.N.; Lorenzoni, I.; O’Brien, K.L. Adapting to Climate Change: Thresholds, Values, Governance; Cambridge University Press: Cambridge, UK, 2009.

5. Sovacool, B.K.; Linnér, B.O. The Political Economy of Climate Change Adaptation; Palgrave Macmillan: London, UK, 2015.

6. Bisaro, A.; Hinkel, J. Governance of social dilemmas in climate change adaptation. Nat. Clim. Chang. 2016, 5, 354-359. [CrossRef]

7. Cross, M.S.; McCarthy, P.D.; Garfin, G.; Gori, D.; Enquist, C.A. Accelerating Adaptation of Natural Resource Management to address Climate Change. Conserv. Biol. 2013, 27, 4-13. [CrossRef] [PubMed]

8. Staudt, A.; Leidner, A.K.; Howard, J.; Brauman, K.A.; Dukes, J.S.; Hansen, L.J.; Paukert, C.; Sabo, J.; Solórzano, L.A. The added complications of climate change: Understanding and managing biodiversity and ecosystems. Front. Ecol. Environ. 2013, 11, 494-501. [CrossRef]

9. Cumming, G.S.; Allen, C.R.; Ban, N.C.; Biggs, D.; Biggs, H.C.; Cumming, D.H.; De Vos, A.; Epstein, G.; Etienne, M.; Maciejewski, K.; et al. Understanding protected area resilience: A multi-scale, social-ecological approach. Ecol. Appl. 2015, 25, 299-319. [CrossRef] [PubMed]

10. Mathevet, R.; Thompson, J.; Folke, C.; Chapin III, F.S. Protected areas and their surrounding territory: Social-ecological systems in the context of ecological solidarity. Ecol. Appl. 2016, 26, 5-16. [CrossRef] [PubMed]

11. Rockström, J.; Steffen, W.; Noone, K.; Persson, Å.; Chapin, F.S., III; Lambin, E.F.; Lenton, T.M.; Scheffer, M.; Folke, C.; Schellnhuber, H.J.; et al. A safe operating space for humanity. Nature 2009, 461, 472-475.

12. Liu, J.; Dietz, T.; Carpenter, S.R.; Alberti, M.; Folke, C.; Moran, E.; Pell, A.N.; Deadman, P.; Kratz, T.; Lubchenco, J.; et al. Complexity of coupled human and natural systems. Science 2007, 317, 5844. [CrossRef] [PubMed] 
13. Virapongse, A.; Brooks, S.; Elizabeth Covelli Metcalf, E.; Zedalis, M.; Gosz, J.; Kliskey, A.; Alessa, L. A social-ecological systems approach for environmental management. J. Environ. Manag. 2016, 178, 83-91. [CrossRef] [PubMed]

14. Crawford, S.; Ostrom, E. A grammar of institutions. Am. Political Sci. Rev. 1995, 89, 582-600. [CrossRef]

15. Bousquet, F.; Robbins, P.; Peloquin, C.; Bonato, O. The PISA grammar decodes diverse human-environment approaches. Glob. Environ. Chang. 2015, 34, 159-171. [CrossRef]

16. Ostrom, E. Understanding Institutional Diversity; Princeton University Press: Princeton, NJ, USA, 2005.

17. Burell, G.; Morgan, G. Sociological Paradigms and Organisational Analysis. Elements of the Sociology of Corporate Life; Ashgate: Burlington, NJ, USA, 1979.

18. Madin, J.S.; Bowers, S.; Schildhauer, M.P.; Jones, M.B. Advancing ecological research with ontologies. Trends Ecol. Evol. 2008, 23, 159-168. [CrossRef] [PubMed]

19. Ostrom, E. Background on the institutional analysis and development framework. Policy Stud. J. 2011, 39, 7-27. [CrossRef]

20. Ostrom, E. A diagnostic approach for going beyond panaceas. Proc. Natl. Acad. Sci. USA 2007, 104, 15181-15187. [CrossRef] [PubMed]

21. Ostrom, E. A general framework for analyzing sustainability of social-ecological systems. Science 2009, 325, 419-422. [CrossRef] [PubMed]

22. Mace, G. Whose conservation? Science 2014, 345, 1558-1560. [CrossRef] [PubMed]

23. Krasner, S.D. International Regimes; Cornell University Press: Ithaca, NY, USA, 1983.

24. Latour, B. Science in Action: How to Follow Scientists and Engineers through Society; Harvard University Press: Cambridge, MA, USA, 1988.

25. Latour, B. Why Has Critique Run Out of Steam? From Matters of Fact to Matters of Concern. Crit. Inq. 2004, 30, 225-248. [CrossRef]

26. Shutz, A. Collected Papers I: The Problem of Social Reality; Springer: London, UK, 1972.

27. Berger, P.L.; Luckmann, T. The Social Construction of Reality; Penguin Book: New York, NY, USA, 1966.

28. Hacking, I. The Social Construction of What? Harvard University Press: Cambridge, MA, USA, 1999.

29. Agrawal, A. Common Property Institutions and Sustainable Governance of Resources. World Dev. 2001, 29, 1649-1672. [CrossRef]

30. Folke, C.; Hahn, T.; Olsson, P.; Norberg, J. Adaptive governance of social-ecological systems. Annu. Rev. Environ. Resour. 2005, 30, 1-8. [CrossRef]

31. Anderies, J.M.; Janssen, M.A.; Schlager, E. Institutions and the Performance of Coupled Infrastructure Systems. Int. J. Commons 2016, 10, 495-516. [CrossRef]

32. Mathevet, R. Uncertain Camargue. Sciences, Uses and Natures; Buchet Chastel: Paris, France, 2004. (In French)

33. Allouche, A.; Nicolas, L. Between perceptions, publicisation and stakeholders' strategies: Coastal risk management inclusion in public policy. VertigO 2015, 21, 15766. (In French)

34. Picon, B. L'espace et le Temps en Camargue; Actes Sud: Arles, France, 1978. (In French)

35. Mathevet, R.; Godet, L. Conservation Geography; L'Harmattan: Paris, France, 2015. (In French)

36. Luglia, R. Des Savants pour Protéger la Nature. La Société D'acclimatation (1854-1960); PUR: Rennes, France, 2015. (In French)

37. Béchet, A.; Rendon-Martos, M.; Rendon, M.A.; AMAT, J.A.; Johnson, A.R.; Gauthier-Clerc, M. Global economy interacts with climate change to jeopardize species conservation: The case of the greater flamingo in the Mediterranean and West Africa. Environ. Conserv. 2012, 39, 1-3. [CrossRef]

38. Mathevet, R.; Peluso, N.; Couespel, A.; Robbins, P. Using Historical Political Ecology to Understand the Present: Water, Reeds and Biodiversity in the Camargue Biosphere Reserve (Southern France). Ecol. Soc. 2015, 20, 17. [CrossRef]

39. IUCN. Environmental Status Reports. Volume Four. Conservation Status of the Danube Delta; IUCN: Norwich, UK, 1992.

40. Iordachi, C. The California of the Romanians: The integration of Northern Dobrogea into Romania, 1878-1913. In Nation Building and Contested Identities, Romanian and Hungarian Case Studies; Iordachi, C., Ed.; Polirom: Iasi, Romania, 2011; pp. 121-152.

41. Dorondel, S.; Mitroi, V. Nature, state and conservation in the Danube Delta. Turning fi shermen into outlaws. In The Nature State: Rethinking the History of Conservation; Von Hardenberg, W.G., Kelly, M., Leal, C., Wakild, E., Eds.; Routledge Press: Abingdon, UK, 2017; pp. 193-211. 
42. Antipa, G. Dunarea si Problemele ei Stiintifice, Economice si Politice. [Le Danube and its Scientific, Economic and Political Problems]; Cartea Romaneasca: Bucarest, Romania, 1921.

43. Gâstescu, P. The Danube Delta Biosphere Reserve. Geography, Biodiversity, Protection, Management. Rom. J. Geogr. 2009, 53, 139-152.

44. Schneider, E. The Danube Delta. Lessons Learned from Nature Restoration Projects. In The Biopolitics of the Danube Delta. Nature, History, Policies; Iordachi, C., Van Assche, K., Eds.; Lexington Books: Plymouth, UK, 2015; pp. 87-114.

45. Navodaru, I.; Staras, M. Conservation of fish stocks in the Danube Delta, Romania: Present status, constraints, and recommendation. Ital. J. Zool. 1998, 65, 369-371. [CrossRef]

46. Mitroi, V.; Billaud, J.P. But what has become the fish from Danube Delta? The moral economies of fisheries degradation in a Biosphere Reserve [in French]. Développement Durable Territoires 2016, 7, 11472.

47. Van Assche, K.; Beunen, R.; Jacobs, J.; Teampau, P. Crossing trails in the marshes: Rigidity and flexibility in the governance of the Danube Delta. J. Environ. Plan. Manag. 2011, 54, 997-1018. [CrossRef]

48. Nel, J.L.; Le Maitre, D.C.; Nel, D.C.; Reyers, B.; Archibald, S.; Van Wilgen, B.W.; Forsyth, G.G.; Theron, A.K.; O'Farrell, P.J.; Kahinda, J.M.M.; et al. Natural Hazards in a Changing World: A Case for Ecosystem-Based Management. PLoS ONE 2014, 9, e95942. [CrossRef] [PubMed]

49. Van Wilgen, B.W.; Esler, K.J.; Gaertner, M.; Esler, K.J.; Forsyth, A.T.; Gaertner, M.; Hoffman, M.T.; Kruger, F.J.; Midgley, G.F.; Palmer, G.; et al. Ecological research and conservation management in the Cape Floristic Region between 1945 and 2015: History, current understanding and future challenges. Trans. R. Soc. S. Afr. 2016, 71, 207-303. [CrossRef]

50. Geldenhuys, C.J. The Effect of Management for Timber Production on Floristics and Growing Stock in the Southern Cape Indigenous Forests. SAFJ 1980, 113, 6-15. [CrossRef]

51. SANParks. Garden Route National Park: Park Management Plan; South African National Parks: Pretoria, South Africa, 2012.

52. Ramutsindela, M. Land reform in South Africa's national parks: A catalyst for the human-nature nexus. Land Use Policy 2003, 20, 41-49. [CrossRef]

53. Crisp, A.G. Development Role Players' Knowledge of Ecological Infrastructure in Eden District, South Africa. Master's Thesis, Nelson Mandela Metropolitan University, George, South Africa, 2015.

54. Faasen, H.; Watts, S. Local community reaction to the "no-take" policy on fishing in the Tsitsikamma National Park, South Africa. Ecol. Econ. 2007, 64, 36-46. [CrossRef]

55. Glavovic, B.C.; Boonzaier, S. Confronting coastal poverty: Building sustainable coastal livelihoods in South Africa. Ocean Coast. Manag. 2007, 50, 1-23. [CrossRef]

56. Lubell, M.; Jasny, L.; Hastings, A. Network Governance for Invasive Species Management. Conserv. Lett. 2017, 10, 699-707. [CrossRef]

57. Barendse, J.; Roux, D.; Currie, B.; Wilson, N.; Fabricius, C. A broader view of stewardship to achieve conservation and sustainability goals in South Africa. S. Afr. J. Sci. 2016, 112, 15. [CrossRef]

58. Roux, D.; Nel, J.L.; Cundill, G.; O'Farrell, P.; Fabricius, C. Transdisciplinary research for systemic change: Who to learn with, what to learn about and how to learn. Sustain. Sci. 2017, 12, 711-726. [CrossRef]

59. Walker, B.; Kinzig, A.; Langridge, J. Plant Attribute Diversity, Resilience, and Ecosystem Function: The Nature and Significance of Dominant and Minor Species. Ecosystems 1999, 2, 95-113. [CrossRef]

60. Carpenter, S.; Walker, B.; Anderies, J.M.; Abel, N. From Metaphor to Measurement: Resilience of What to What? Ecosystems 2001, 4, 765-781. [CrossRef]

61. Folke, C.; Colding, J.; Berkes, F. Synthesis: Building resilience and adaptive capacity in social-ecological systems. In Navigating Social-Ecological Systems; Berkes, F., Colding, J., Folke, C., Eds.; Cambridge University Press: Cambridge, UK, 2003; pp. 352-387.

62. Jones, P.J.S.; Qiu, W.; De Santo, E.M. Governing marine protected areas: Social-ecological resilience through institutional diversity. Mar. Policy 2013, 41, 5-13. [CrossRef]

63. Baggio, J.A.; Barnett, A.J.; Perez-Ibarra, I.; Brady, U.; Ratajczyk, E.; Rollins, N.; Rubiños, C.; Shin, H.; Yu, D.; Aggarwal, R.; et al. Explaining success and failure in the commons: The configural nature of Ostrom's institutional design principles. Int. J. Commons 2016, 10, 417-439. [CrossRef]

64. Plummer, R. Can adaptive comanagement help to address the challenges of climate change adaptation? Ecol. Soc. 2013, 18, 2. [CrossRef] 
65. Stein, B.A.; Staudt, A.; Cross, M.S.; Dubois, N.S.; Enquist, C.; Griffis, R.; Hansen, L.J.; Hellmann, J.J.; Lawler, J.J.; Nelson, E.J.; et al. Preparing for and managing change: Climate adaptation for biodiversity and ecosystems. Front. Ecol. Environ. 2013, 11, 502-510. [CrossRef]

66. Eisenack, K.; Moser, S.C.; Hoffmann, E.; Klein, R.J.; Oberlack, C.; Pechan, A.; Rotter, M.; Termeer, C.J. Explaining and overcoming barriers to climate change adaptation. Nat. Clim. Chang. 2014, 4, 867-872. [CrossRef]

67. Mawdsley, J.R.; O'Malley, R.; Ojima, D.S. A review of climate-change adaptation strategies for wildlife management and biodiversity conservation. Conserv. Biol. 2009, 23, 1080-1089. [CrossRef] [PubMed]

68. Barnett, J.; Graham, S.; Mortreux, C.; Fincher, R.; Waters, E.; Hurlimann, A. A local coastal adaptation pathway. Nat. Clim. Chang. 2014, 4, 1103-1108. [CrossRef]

69. Orach, K.; Schlüter, M. Uncovering the political dimension of social-ecological systems: Contributions from policy process frameworks. Glob. Environ. Chang. 2016, 40, 13-25. [CrossRef]

70. Grantham, H.S.; Bode, M.; McDonald-Madden, E.; Game, E.T.; Knight, A.T.; Possingham, H.P. Effective conservation planning requires learning and adaptation. Front. Ecol. Environ. 2010, 8, 431-437. [CrossRef]

71. Armsworth, P.R.; Larson, E.R.; Jackson, S.T.; Sax, D.F.; Simonin, P.; Blossey, B.; Green, N.; Klein, M.L.; Lester, L.; Ricketts, T.H.; et al. Are conservation organizations configured for effective adaptation to global change? Front. Ecol. Environ. 2015, 13, 163-169. [CrossRef]

(C) 2018 by the authors. Licensee MDPI, Basel, Switzerland. This article is an open access article distributed under the terms and conditions of the Creative Commons Attribution (CC BY) license (http://creativecommons.org/licenses/by/4.0/). 